の值は他のベンゼン代謝物より低い，MHAはキシレン 類約 77〜125 ppbで対照と弁別可能であった.

\section{6. 岡山県内の事業場における有機溶剤使用の現状}

○秀衡隆志 ${ }^{1}$, 岸本卓已 ${ }^{2}$, 内田玄桂 ${ }^{2}$, 関 明彦 $^{1}$, 正富千絵 ${ }^{1}$, 中山祥嗣 ${ }^{1}$, 吉良尚平 ${ }^{1,2}$

( ${ }^{1}$ 岡山大·医・公衆衛生, ${ }^{2}$ 岡山産業保健推進センター)

岡山県内の有機溶剂使用事業場における健康診断の実 施状況と環境測定調査の現況を把握するため調査を行っ た．対象は，有機溶凨管理資格者を有する 962 社で，方 法はアンケート郵送法により行った。調查期間は 1998-99年であった。

回答は 286 社（回答率 $29.7 \%$ ) からあり，そのうち尿 中代謝物検查を要する有機溶凨を使用しているのは 256 社 $(89.5 \%)$ あった。

その結果, 岡山県ではトルエン, キシレンの使用頻度 が高かった，塩素系溶哓については，約 1 割の事業場が 今でもトリクロルエチレンを使っていた。 その用途の約 6 割は金属製品や部品の洗浄であった．また，トルエン の場合, 第 1 管理区分から分布 1 の事業場は約半数あり,

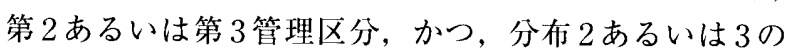
ものが 1 割以上あった. 以上の結果は, 作業環境改善が 望まれる事業場も少なくないことを示している.

\section{7. 建材塗料における最近の動向と作業者の有機溶剤曝露} ○川島麻以子 ${ }^{1}$, 高橋克明 ${ }^{1}$, 青末志乃 ${ }^{1}$, 神田秀人 ${ }^{1}$, 大原昭男 ${ }^{2}$, 高倉敏行 ${ }^{1}$, 山口恭平 ${ }^{1}$, 藤木幸雄 ${ }^{2}$ ( ${ }^{1}$ 松下産業衛生科学センター 東京支所, 2 松下産業衛生科学センター) 最近の住宅内装建材用塗装は有機溶剤を含有しない （有機溶剂中毒予防規則に該当しない）又は含有成分量 の少ない紫外線硬化型 (UV) 樹脂塗料が使用されるよ うになってきたししい，こうしたUV塗料を扱う場所 でも作業者から臭気に対する訴えがみられる。そこで今 回, UV 塗料を扱方作業者の個人曝露濃度測定と生物学 的モニタリング，またUV 塗料について有機溶郕成分の 定性・定量分析を行った。

結果は有機溶凨を含有しない塗料を使用する作業者 で, 有機溶郕曝露を認めた。また塗料成分分析の結果, 数種類の有機浴剂成分が確認された，有機溶剤含有成分 量の少ない塗料についても，表示外成分が確認された.

現在, 生物学的モニタリングの対象者は有機溶梸の含 有量で決定されるが，使用量，使用する作業場の気積， 精密な取り扱い物質の把握, 作業環境測定や個人曝露濃 度測定といった多くのパラメータから, 総合的に選定す る必要性があると考える。

\section{8. 日本中毒情報センターに問い合わせのあった有機溶 剮中毒の現状}

石沢淳子，辻川明子，尾形み妕き， 黑木由美子，後藤京子，大橋教良 （財）日本中毒情報センター）

日本中毒情報センターで1998年に受信したヒトの急 性中毒 34,549 件のうち家庭用品の中で有機溶剤を主体 とする製品と工業用の有機溶剂による中毒 1067 件を対 象として調查した。状況は不慮の事故 $82 \%$, 労災, 自 殺企図各 $6 \%$ で，患者は5 歳以下 $71 \%, 20 \sim 64$ 歳 $21 \%$ であった，症状出現率は不慮の事故 $14 \%$, 労災 $87 \%$, 自殺企図 $73 \%$ で, 曝露経路は不慮の事故では経口, 労 災では吸入が多かった。起因物質は灯油が多く，マニキ ユア除光液, シンナー, 潤滑油, 塗料, 着火液, 家庭用 しみぬき剤の順であった．労災では塩化メチレン，トリ クロロエチレン等の塩素系炭化水素, シンナー, フロン 類が $51 \%$ 占めた.

受糡時にMSDSを持参する例は少なく，事業所にも 備えていないために製品や成分の確認に支障をきたす例

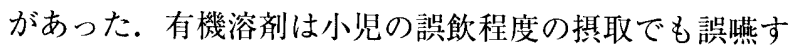
ると化学性肺炎を起こすことがあり, 有機溶剤中毒の危 険性やMSDS の活用をさらに啓蒙する必要がある.

\section{9. 産業職場における有機溶剤の発散状況（その 2) 一セロソルブ類一}

○村田和弘, 久保田義彦, 池田政生, 今井 隆, 木村真次 （近畿健康管理センター）

動物に対して生殖毒性（精巣萎縮）が明らかにされて いるセロソルブ類の環境気中への発散状況について調査 した。調查対象は平成 8 年 4 月から平成 10 年 3 月の間で 当センターにて，七ロソルブ類の作業環境測定を実施し た 54 事業所 (実数), 214 単位作業場所（延べ）とした。 セロソルブ類は塗装, 印刷, 面の加工, 接着, 塗料製造 等の作業場で使用されており，ブチルセロソルブが 141 件 $(59 \%)$ と最も多く, 次いでセロソルブアセテート

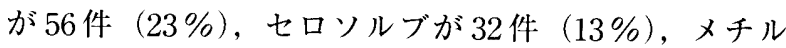
セロソルブが 12 件 $(5 \%)$ であり，七ロソルブ類の $90 \%$ が混合溶剂として使用されていた，各セロソルブ 類について単一溶剤として評価した作業環境の管理区分 は，5\%の作業場が第 2 あるいは第3管理区分であった。 セロソルブ類は沸点が比較的高く蒸気圧が比較的低いた め, 常温下での測定值はいずれも $10 \mathrm{ppm}$ を下回ってお り，局排対策を十分に講じれば環境気中への発散を抑制 できると考えられた。 